\title{
Studies on the Effect of Time of Wedge Grafting and Growing Conditions on Growth and Leaf Characteristics of Guava (Psidium guajava L.) Grafts
}

\author{
L. Vanaja*, D.V. Swami, B. Prasanna Kumar and P. Subbaramamma \\ College of Horticulture, Dr. Y.S.R.Horticultural University, Venkataramannagudem, West \\ Godavari District-534101, A.P., India \\ *Corresponding author
}

\section{A B S T R A C T}

\begin{tabular}{|l|}
\hline K e y w o r d s \\
Guava, Grafting time, \\
poly house and shade \\
net conditions, Leaf \\
characters, Wedge \\
grafting.
\end{tabular}

\section{Introduction}

Guava (Psidium guajava L.), the poor man's apple and "apple of tropics" belongs to the family Myrtaceae, is considered to be one of the exquisite, nutritionally valuable and remunerative crops. Besides its high nutritional value, it bears heavy crop every year and gives good economic returns. This has prompted several farmers to take up guava orcharding on a commercial scale. In recent years, guava is getting popularity in the international trade due to its nutritional value and processed products. Guava is highly cross pollinated crop and the seed being a heterozygous in nature, it is not possible to get true-to-type plants through seeds. However, the greatest handicap in guava plantation is discriminate multiplication of plants from unreliable sources by nurserymen (Singh et al., 2005). Non-availability of quality planting materials and consequent substitution of poor quality seedlings have adversely affected the guava production and productivity. The planting material is the best requirement for any fruit crop because it influences the ultimate yield both in terms of quality and quantity (Singh et al., 2005). The scenario is changing from traditional propagation with incorporation of science and technology to nursery management and trade. In view of the high return and the potential for processing, there is a tremendous scope for bringing substantial additional area under guava crop in India. So, a rapid and successful propagation technique is required 
as the area under crop is expanding and there is a demand to prepare the guava sampling throughout the year. While choosing a particular technique for propagation of guava, the time of wedge grafting and climatic conditions should be taken into consideration.

In the present context, use of rapid multiplication methods become very important when planting material was limited for improved varieties or clones. Though, guava is propagated through air-layering, stooling, grafting and inarching and still not commercially viable due to varying rates of success due to absence of tap root system and involving cumbersome process for its multiplication.

Keeping in view of these facts, the investigation was carried out on the response of wedge grafting under poly house and shade net conditions to ensure success of grafts growth and large scale multiplication of superior planting material in guava.

\section{Materials and Methods}

An experiment was carried during 2014-2015 at the Horticultural College and Research Institute, Venkataramannagudem, West Godavari District, Andhra Pradesh. Wedge grafting was performed during seven months, viz., August $\left(\mathrm{M}_{1}\right)$, September $\left(\mathrm{M}_{2}\right)$, October $\left(\mathrm{M}_{3}\right)$, November $\left(\mathrm{M}_{4}\right)$, December $\left(\mathrm{M}_{5}\right)$, January $\left(\mathrm{M}_{6}\right)$ and February $\left(\mathrm{M}_{7}\right)$ and grown under poly house as well as in $50 \%$ shade net conditions. There were fourteen treatment combinations replicated thrice in a Factorial Randomized Block Design. The grafting was done on 6 to 8-month old rootstock, which has attained a stem diameter of $0.5-1.0 \mathrm{~cm}$. The scion shoots of $15-18 \mathrm{~cm}$ long of pencil thickness $(0.5$ to $1.0 \mathrm{~cm})$ with 3 to 4 healthy buds were selected for grafting. Selected scions were defoliated on the mother plant, about one week prior to grafting. At the same time apical growing portion of selected shoots was also beheaded, which helped in forcing the dormant grafts to swell. In this way, the grafts on the scion were ready to start sprouting at the time of grafting. The scion stick was inserted into the split of the stock and pressed properly so that cambium tissue of rootstock and scion could come into contact with each other. The observations were recorded on leaf characters such as number of leaves per sprout, leaf area per sprout and leaf chlorophyll content.

\section{Number of leaves per sprout}

The number of leaves per successful graft sprout was recorded at 15 days interval starting from $30^{\text {th }}$ DAG to $120^{\text {th }}$ DAG for five randomly selected grafts in each replication. The average number of leaves per successful graft sprout were calculated and expressed in number.

\section{Leaf area per sprout $\left(\mathrm{cm}^{2}\right)$}

The leaf area per successful graft sprout was recorded at 15 days interval starting from $30^{\text {th }}$ DAG to $120^{\text {th }}$ DAG by using scale to measure the length and breadth of leaf for five randomly selected grafts in each replication.

The apparent leaf area obtained by multiplying length and breadth is reduced to actual leaf area by correcting with constant $\mathrm{k}$. The average leaf area per sprout was calculated by employing the following formula as suggested by Watson (1952) and expressed in $\mathrm{cm}^{2}$.

Leaf area $(A)=k \times L \times B$; where

$\mathrm{A}=$ leaf area

$\mathrm{L}=$ Length of leaf

$\mathrm{B}=$ Breadth of leaf

$\mathrm{k}=0.635$ constant value

$\mathrm{L}$ and $\mathrm{B}$ are maximum length and breadth at right angle to each other respectively and $\mathrm{k}$ is 
constant determined for species under investigation.

\section{Leaf chlorophyll content (SPAD units)}

The leaf chlorophyll content of successful grafts were estimated at 15 days interval starting from $30^{\text {th }}$ DAG to 120 days by using SPAD chlorophyll meter for five randomly selected grafts in each replication. The average leaf chlorophyll content was calculated and expressed in SPAD units.

\section{Results and Discussion}

The number of leaves per sprout was more in the grafts prepared under shade net condition $(1.85,3.04,5.62,8.22,10.72,13.60$, and 15.69 at $30,45,60,75,90,105$ and 120 DAG respectively) than under poly house condition.

Significant differences were observed among the time of wedge grafting for number of leaves per sprout at all days after grafting. The number of leaves per sprout was gradually increased from 30 DAG to 120 DAG. The number of leaves per sprout was more in the plants grafted during January month $(3.33,5.18,7.71,10.88$ and 14.23 at $30,45,60,75,90,105$ and 120 DAG respectively) followed by August month. The number of leaves per sprout was less in the grafts prepared during September month (Table 1).

The interaction between growing conditions and time of wedge grafting was found significant for number of leaves per sprout at all days after grafting. The maximum number of leaves per sprout $(3.40,4.33,7.46,11.63$, $16.70,19.23$ and 24.13 at $30,45,60,75,90$, 105 and 120 DAG respectively) was observed in the grafts prepared during August month under poly house conditions. The minimum number of leaves per sprout was observed in the grafts prepared during September month under shade net condition.
It could be due to auxins and prevailing favourable environmental conditions helps in the formation of more number of leaves per sprout through proper development of intercalary meristem at nodal regions (Taiz and Zeiger, 2012). These results are in agreement with the earlier findings of Singh and Singh, (2006) in guava; Syamal et al., (2012); Beer et al., (2013); Joshi et al., (2014) and Mahendra et al., (2015) in guava.

The leaf area per sprout $(15.20,17.77,22.99$, 25.77, 28.86, 32.73 and $36.01 \mathrm{~cm}^{2}$ at 30,45 , $60,75,90,105$ and 120 DAG respectively) was high in plants grafted under shade net condition than under poly house condition.

Significant differences were observed among the time of wedge grafting for leaf area per sprout at all days after grafting. The leaf area per sprout $(25.63,31.94,37.09,44.47,49.05$ and $56.19 \mathrm{~cm}^{2}$ at $45,60,75,90,105$ and 120 DAG respectively expect $30 \mathrm{DAG}$ ) was high in the grafts prepared during August month followed by December month. The leaf area per sprout $(2.75,3.14,3.31,3.45,3.53,3.96$ and $4.31 \mathrm{~cm}^{2}$ at $30,45,60,75,90,105$ and 120 DAG respectively) was low in the plants grafted during September month (Table 2).

The interaction between growing condition and time of wedge grafting was found significant for leaf area per sprout at all days after grafting.

The maximum leaf area per sprout (26.45, $32.42,39.55,47.74,58.51,63.42$ and 74.26 $\mathrm{cm}^{2}$ at $30,45,60,75,90,105$ and 120 DAG respectively) was observed in the grafts prepared during August month under poly house conditions. The minimum leaf area per sprout $(2.55,3.07,3.18,3.44,3.52,3.81$ and $4.15 \mathrm{~cm}^{2} 30,45,60,75,90,105$ and 120 DAG respectively) was observed in the grafts prepared during September month under poly house condition. 
Table.1 Effect of growing conditions, time of wedge grafting and their interaction on number of leaves per sprout in guava

\begin{tabular}{|c|c|c|c|c|c|c|c|c|c|c|c|c|c|c|c|c|c|c|c|c|c|}
\hline \multirow{3}{*}{ Treatments } & \multicolumn{21}{|c|}{ Number of leaves per sprout } \\
\hline & \multicolumn{3}{|c|}{ 30 DAG } & \multicolumn{3}{|c|}{45 DAG } & \multicolumn{3}{|c|}{60 DAG } & \multicolumn{3}{|c|}{75 DAG } & \multicolumn{3}{|c|}{90 DAG } & \multicolumn{3}{|c|}{105 DAG } & \multicolumn{3}{|c|}{120 DAG } \\
\hline & $\mathrm{C}_{1}$ & $\mathbf{C}_{2}$ & Mean & $\mathbf{C}_{1}$ & $\mathbf{C}_{2}$ & Mean & $\mathbf{C}_{1}$ & $\mathbf{C}_{2}$ & Mean & $\mathbf{C}_{1}$ & $\mathrm{C}_{2}$ & Mean & $\mathbf{C}_{1}$ & $\mathbf{C}_{2}$ & Mean & $\mathbf{C}_{1}$ & $\mathbf{C}_{2}$ & Mean & $\mathbf{C}_{1}$ & $\mathbf{C}_{2}$ & Mean \\
\hline $\mathbf{M}_{1}$ & 1.13 & 3.40 & 2.26 & 2.70 & 4.33 & 3.51 & 5.90 & 7.46 & 6.68 & 8.06 & 11.63 & 9.85 & 10.33 & 16.70 & 13.51 & 13.83 & 19.23 & 16.53 & 15.93 & 24.13 & 20.03 \\
\hline $\mathbf{M}_{2}$ & 0.17 & 0.10 & 0.13 & 0.30 & 0.17 & 0.23 & 0.47 & 0.37 & 0.42 & 0.60 & 0.47 & $\mathbf{0 . 5 3}$ & 0.67 & 0.60 & 0.63 & 0.73 & 0.66 & 0.70 & 0.80 & 0.73 & 0.77 \\
\hline $\mathbf{M}_{3}$ & 1.00 & 0.80 & 0.90 & 2.30 & 2.23 & 2.26 & 5.16 & 4.66 & 4.91 & 7.43 & 6.56 & $\mathbf{7 . 0 0}$ & 9.86 & 8.40 & 9.13 & 13.63 & 10.50 & 12.06 & 15.60 & 14.70 & $\mathbf{1 5 . 1 5}$ \\
\hline $\mathbf{M}_{4}$ & 1.30 & 0.53 & 0.91 & 2.96 & 0.90 & 1.93 & 6.13 & 1.50 & 3.81 & 8.26 & 2.23 & 5.25 & 11.36 & 5.50 & 8.43 & 14.50 & 7.23 & 10.86 & 16.40 & 9.26 & 12.83 \\
\hline $\mathbf{M}_{5}$ & 2.10 & 2.70 & 2.40 & 2.50 & 3.63 & 3.06 & 6.53 & 7.26 & 6.90 & 10.40 & 11.16 & 10.78 & 13.70 & 14.43 & 14.06 & 16.23 & 18.60 & 17.41 & 18.80 & 22.00 & 20.40 \\
\hline $\mathbf{M}_{6}$ & 5.16 & 1.50 & $\mathbf{3 . 3 3}$ & 7.16 & 3.20 & 5.18 & 8.76 & 6.66 & 7.71 & 12.53 & 9.23 & 10.88 & 15.90 & 12.56 & 14.23 & 19.26 & 15.43 & 17.35 & 23.20 & 16.66 & 19.93 \\
\hline $\mathbf{M}_{7}$ & 2.10 & 0.73 & 1.41 & 3.43 & 1.76 & 2.60 & 6.56 & 2.16 & 4.36 & 10.56 & 4.56 & 7.56 & 13.60 & 6.66 & 10.13 & 17.43 & 8.43 & \begin{tabular}{|l|}
12.93 \\
\end{tabular} & 19.60 & 10.10 & 14.85 \\
\hline \multirow[t]{2}{*}{ Mean } & 1.85 & 1.42 & & 3.04 & 2.34 & & 5.62 & 4.29 & & 8.22 & 6.53 & & 10.72 & 9.22 & & 13.60 & 11.39 & & 15.69 & 13.88 & \\
\hline & SE(m) & \multicolumn{2}{|c|}{ C.D (5\%) } & SE(m) & \multicolumn{2}{|c|}{ C.D (5\%) } & SE(m) & \multicolumn{2}{|c|}{ C.D (5\%) } & SE(m) & \multicolumn{2}{|c|}{ C.D (5\%) } & SE(m) & \multicolumn{2}{|c|}{ C.D (5\%) } & SE(m) & \multicolumn{2}{|c|}{ C.D (5\%) } & $\mathrm{SE}(\mathrm{m})$ & \multicolumn{2}{|c|}{ C.D (5\%) } \\
\hline Factor -1 & 0.04 & \multicolumn{2}{|c|}{0.10} & 0.05 & \multirow{2}{*}{\multicolumn{2}{|c|}{$\begin{array}{l}0.15 \\
0.28\end{array}$}} & 0.05 & \multicolumn{2}{|c|}{0.17} & 0.08 & \multicolumn{2}{|c|}{0.23} & 0.11 & \multicolumn{2}{|c|}{0.33} & 0.14 & \multicolumn{2}{|c|}{0.42} & 0.17 & \multicolumn{2}{|c|}{0.50} \\
\hline Factor -2 & 0.08 & \multirow{2}{*}{\multicolumn{2}{|c|}{$\begin{array}{l}0.23 \\
0.33\end{array}$}} & 0.09 & & & 0.10 & \multirow{2}{*}{\multicolumn{2}{|c|}{$\begin{array}{l}0.31 \\
0.44 \\
\end{array}$}} & 0.15 & & & 0.21 & \multirow{2}{*}{\multicolumn{2}{|c|}{$\begin{array}{l}0.61 \\
0.87 \\
\end{array}$}} & 0.27 & 0 . & & 0.32 & & 95 \\
\hline Interaction $(1 \times 2)$ & 0.11 & & & 0.13 & \multicolumn{2}{|c|}{0.39} & 0.13 & & & 0.21 & \multicolumn{2}{|c|}{0.62} & 0.29 & & & 0.38 & 1. & & 0.46 & & 34 \\
\hline Factor -1 & & & & $\mathrm{C}_{1}=$ Sha & e net & & & $\mathrm{C}_{2}=$ & Polyhou & & & & & & & & & & & & \\
\hline Factor -2 & & & & $\mathbf{M}_{1}=\mathbf{A u}$ & & & & $\mathbf{M}_{2}$ & Septem & & & $\mathbf{M}_{3}=$ & October & & & $\mathbf{M}_{4}$ & Noveml & & & & \\
\hline & & & & $\mathrm{M}_{5}=\mathrm{De}$ & mber & & & $\mathbf{M}_{6}$ & Januar & & & $\mathbf{M}_{7}=$ & February & & & & & & & & \\
\hline DAG & & & & Days Af & r Graf & & & & & & & & & & & & & & & & \\
\hline
\end{tabular}

Table.2 Effect of growing conditions, time of wedge grafting and their interaction on leaf area per sprout in guava

\begin{tabular}{|c|c|c|c|c|c|c|c|c|c|c|c|c|c|c|c|c|c|c|c|c|c|}
\hline \multirow{3}{*}{ Treatments } & \multicolumn{21}{|c|}{ Leaf area per sprout $\left(\mathrm{cm}^{2}\right)$} \\
\hline & \multicolumn{3}{|c|}{30 DAG } & \multicolumn{3}{|c|}{45 DAG } & \multicolumn{3}{|c|}{ 60 DAG } & \multicolumn{3}{|c|}{75 DAG } & \multicolumn{3}{|c|}{90 DAG } & \multicolumn{3}{|c|}{105 DAG } & \multicolumn{3}{|c|}{120 DAG } \\
\hline & $\mathrm{C}_{1}$ & $\mathrm{C}_{2}$ & Mean & $\mathrm{C}_{1}$ & $\mathbf{C}_{2}$ & Mean & $\mathrm{C}_{1}$ & $\mathrm{C}_{2}$ & Mean & $\mathrm{C}_{1}$ & $\mathrm{C}_{2}$ & Mean & $\mathrm{C}_{1}$ & $\mathrm{C}_{2}$ & Mean & $\mathrm{C}_{1}$ & $\mathrm{C}_{2}$ & Mean & $\mathrm{C}_{1}$ & $\mathrm{C}_{2}$ & Mean \\
\hline $\mathbf{M}_{1}$ & 14.24 & 26.45 & 20.34 & 18.85 & 32.42 & 25.63 & 24.33 & 39.55 & 31.94 & 26.45 & 47.74 & 37.09 & 30.43 & 58.51 & 44.47 & 34.68 & 63.42 & 49.05 & 38.12 & 74.26 & 56.19 \\
\hline $\mathbf{M}_{2}$ & 2.96 & 2.55 & 2.75 & 3.22 & 3.07 & 3.14 & 3.44 & 3.18 & 3.31 & 3.47 & 3.44 & 3.45 & 3.55 & 3.52 & $\mathbf{3 . 5 3}$ & 4.11 & 3.81 & 3.96 & 4.47 & 4.15 & 4.31 \\
\hline $\mathbf{M}_{3}$ & 13.26 & 9.39 & 11.33 & 16.77 & 12.46 & 14.62 & 22.87 & 13.70 & 18.28 & 24.25 & 17.36 & 20.80 & 28.65 & 20.43 & 24.54 & 32.53 & 22.65 & 27.59 & 34.62 & 24.53 & 29.57 \\
\hline $\mathbf{M}_{4}$ & 16.58 & 10.36 & 13.47 & 19.73 & 13.22 & 16.47 & 25.31 & 15.36 & 20.34 & 28.47 & 19.43 & 23.95 & 32.66 & 25.29 & 28.97 & 36.42 & 27.57 & 32.00 & 40.47 & 28.32 & 34.39 \\
\hline$M_{5}$ & 19.45 & 24.45 & 21.95 & 21.33 & 26.43 & 23.88 & 28.68 & 32.43 & 30.56 & 32.67 & 36.86 & 34.77 & 35.20 & 41.47 & 38.34 & 40.29 & 46.57 & 43.43 & 44.57 & 50.30 & 47.44 \\
\hline$M_{6}$ & 21.70 & 12.47 & 12.47 & 23.70 & 14.88 & 19.29 & 29.38 & 17.55 & 23.46 & 34.59 & 22.79 & 28.69 & 37.73 & 26.52 & 32.12 & 42.51 & 29.60 & 36.05 & 46.50 & 31.46 & 38.98 \\
\hline $\mathbf{M}_{7}$ & 18.24 & 8.98 & 13.61 & 20.83 & 10.45 & 15.64 & 26.94 & 11.26 & 19.09 & 30.48 & 15.74 & 23.11 & 33.83 & 16.34 & 25.08 & 38.58 & 18.64 & 28.61 & 43.33 & 20.65 & 31.99 \\
\hline \multirow[t]{2}{*}{ Mean } & 15.20 & 13.52 & & 17.77 & 16.13 & & 22.99 & 19.00 & & 25.77 & 23.34 & & 28.86 & 27.44 & & 32.73 & 30.32 & & 36.01 & 33.38 & \\
\hline & SE(m) & \multicolumn{2}{|c|}{ C.D (5\%) } & SE(m) & \multicolumn{2}{|c|}{ C.D (5\%) } & SE(m) & \multicolumn{2}{|c|}{ C.D $(5 \%)$} & SE(m) & \multicolumn{2}{|c|}{ C.D (5\%) } & SE(m) & \multicolumn{2}{|c|}{ C.D (5\%) } & SE(m) & \multicolumn{2}{|c|}{ C.D (5\%) } & SE(m) & \multicolumn{2}{|c|}{ C.D (5\%) } \\
\hline Factor -1 & 0.38 & \multicolumn{2}{|c|}{1.11} & 0.43 & \multicolumn{2}{|c|}{1.26} & 0.45 & \multicolumn{2}{|c|}{1.32} & 0.47 & \multicolumn{2}{|c|}{1.38} & 0.48 & \multicolumn{2}{|c|}{1.41} & 0.54 & \multicolumn{2}{|c|}{1.60} & 0.85 & \multicolumn{2}{|c|}{2.50} \\
\hline Factor -2 & 0.71 & \multirow{2}{*}{\multicolumn{2}{|c|}{2.07}} & 0.80 & \multirow{2}{*}{\multicolumn{2}{|c|}{$\begin{array}{l}2.35 \\
3.33\end{array}$}} & 0.84 & \multirow{2}{*}{\multicolumn{2}{|c|}{$\begin{array}{l}2.47 \\
3.49 \\
\end{array}$}} & 0.88 & \multirow{2}{*}{\multicolumn{2}{|c|}{$\begin{array}{l}2.58 \\
3.66 \\
\end{array}$}} & 0.90 & \multirow{2}{*}{\multicolumn{2}{|c|}{$\begin{array}{l}\frac{2.65}{3.75} \\
\end{array}$}} & 1.02 & 2. & 99 & 4.68 & & \\
\hline Interaction $(1 \times 2)$ & 1.00 & & & 1.14 & & & 1.19 & & & 1.25 & & & 1.28 & & & 1.45 & & 23 & 6.62 & & \\
\hline Factor -1 & & & & $\mathrm{C}_{1}=$ Sha & e net & & & $\mathrm{C}_{2}=\mathrm{Pc}$ & yhouse & & & & & & & & & & & & \\
\hline Factor -2 & & & & $\mathbf{M}_{1}=\mathbf{A u}$ & & & & $\mathbf{M}_{2}=\mathrm{S}$ & ptember & & & $\mathbf{M}_{3}=$ & October & & & & $=$ Novem & ber & & & \\
\hline & & & & $M_{5}=\mathrm{De}$ & mber & & & $M_{6}=J$ & nuary & & & $\mathbf{M}_{7}=$ & February & & & & & & & & \\
\hline DAG & & & & Days Af & r Graft & & & & & & & & & & & & & & & & \\
\hline
\end{tabular}




\section{Int.J.Curr.Microbiol.App.Sci (2017) 6(10): 1574-1580}

Table.3 Effect of growing conditions, time of wedge grafting and their interaction on leaf chlorophyll content in guava

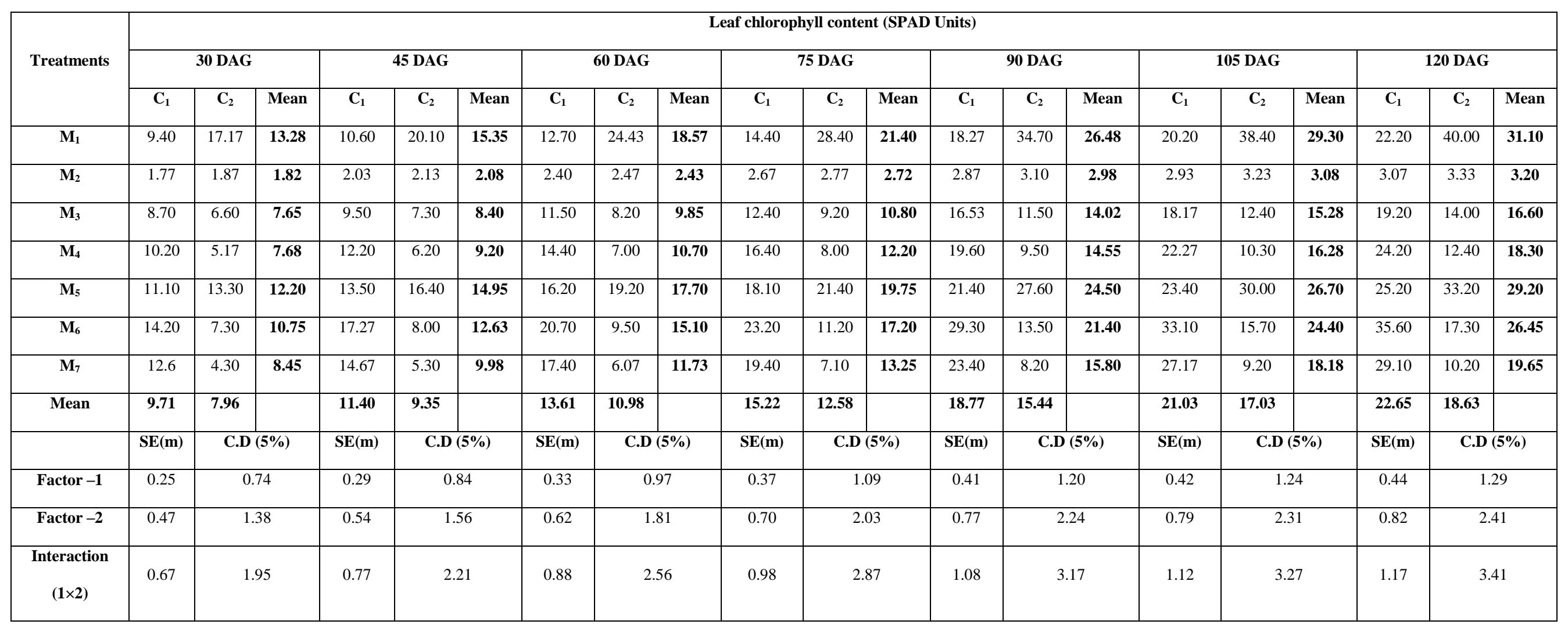

\begin{tabular}{|l|l|l|l|l|}
\hline Factor -1 & $\mathbf{C}_{1}=$ Shade net & $\mathbf{C}_{2}=$ Polyhouse & \\
\hline Factor -2 & $M_{1}=$ August & $\mathbf{M}_{2}=$ September & $\mathbf{M}_{3}=$ October & $\mathbf{M}_{4}=$ November \\
\hline & $M_{5}=$ December & $\mathbf{M}_{6}=$ January & $\mathbf{M}_{7}=$ February \\
\hline DAG & Days After Grafting & & \\
\hline
\end{tabular}


The leaf chlorophyll content (9.71, 11.40, 13.61, 15.22, 18.77, 21.03, 22.65 SPAD units at $30,45,60,75,90,105$ and 120 DAG respectively) was more in the grafts prepared under shade net condition than under poly house condition $(7.96,9.35,10.98,12.58$, 15.44, 17.03 and 18.63 SPAD units at 30, 45, $60,75,90,105$ and 120 DAG respectively).

The differences among the time of wedge grafting were found significant for leaf chlorophyll content. The maximum leaf chlorophyll content $(13.28,15.35,18.57$, $21.40,26.48,29.30$ and 31.10 SPAD units at $30,45,60,75,90,105$ and 120 DAG respectively) was noticed in the grafts prepared during August month followed by December month. The minimum leaf chlorophyll content $(1.82,2.08,2.43,2.72$, $2.98,3.08$ and 3.20 SPAD units at 30, 45, 60, $75,90,105$ and 120 DAG respectively) was observed in the grafts made during September month (Table 3).

The interaction between growing conditions and time of grafting was found significant for leaf chlorophyll content. The leaf chlorophyll content $(17.17,20.10,24.43,28.40,34.70$, 38.40 and 40.00 SPAD units at $30,45,60,75$, 90,105 and 120 DAG respectively) was more in the grafts prepared during August month under poly house conditions. The leaf chlorophyll content $(1.77,2.03,2.40,2.67$, 2.87, 2.93 and 3.07 SPAD units at 30, 45, 60, $75,90,105$ and 120 DAG respectively) was less in the grafts made during September month under shade net condition.

A perusal of the results revealed that, grafts prepared in the month of August under poly house condition recorded the maximum number of leaves per sprout, leaf area per sprout and leaf chlorophyll content. This might be due to the fact that warmer and humid air inside the polyhouse induces the soil to warm up. Plants grafted in the month of August showed better performance which might be due to favourable conditions (moderate humidity i.e. from $25 \%$ to $75 \%$ and optimum temperature i.e. from $24^{\circ} \mathrm{C}$ to $35^{\circ} \mathrm{C}$ ) adequate supply of soil moisture and availability of dormant and swollen terminal buds of scion in bulging condition, which encouraged the maximum growth. These results are in agreement with the results of Singh and Singh (2006) in guava; Lal et al., (2007) in kiwi fruit; Mir and Kumar (2011) in walnut; Raghavendra et al., (2011) in wood apple; Beer et al., (2013) in guava; Syamal et al., (2012) in guava; Anushma et al., (2014) in jamun; Sivudu et al., (2014) in mango; Joshi et al., (2014) and Mahendra et al., (2015) in guava. On the basis of results obtained from the present investigation, it can be concluded that the best results were obtained in the plants grafted during August month under poly house condition is more favorable for maximum number of leaves per sprout, leaf area per sprout and leaf chlorophyll content.

\section{Acknowledgement}

We are thankful to the Department of Fruit science, Horticultural College and Research Institute, Venkataramannagudem, Dr. YSRHU, West Godavari District, Andhra Pradesh, for providing their valuable services and helping us for the successful completion of our project.

\section{References}

Anushma, P.L., Swamy, G.S.K., and Gangadhara, K. 2014. Effect of colored shade nets on softwood grafting success in jamun (Syzigium cuminii skeels). Plant Archives. 14(1): 293-95.

Beer, K., Yada, A.L. and Akhilendra, V. 2013. Effect of grafting time and environment on the graft success of guava (Psidium guajava L.) under 
wedge grafting. Trends in Biosciences.6 (6): 770-772.

Joshi, M., Syamal, M.M. and Singh, S.P. 2014. Comparative efficacy of different propagation techniques in guava. Indian Jour. of Hort. 71(3): 315-20.

Lal, H., Singh, V.P., and Jayant Raman. 2007. Effect of environments and timing on grafting success in kiwi fruit. Annals of Agri. Res. New series. 28(1):35-36.

Mahendra, J., Yogesh, S., Singh, S.S. and Mishra, S.P. 2015. To Study the suitable period of wedge grafting in guava under different condition of Chitrakoot Region. American I. Jour. of Res. in Formal, Applied \& Nat. Sci. 9(1):30-32.

Mir, M., and Kumar, A. 2011.Effect of different methods, time and environmental conditions on grafting in walnut.I. Jour. of Farm Sci.1 (2):17-22.

Raghavendra, V.N., Angadi, S.G., Allolli, T. B., Venugopal, C.K. and Mummigatti, U.V. 2011. Studies on softwood grafting in wood apple (Feronia limonia L.). Karn. Jour. of Agri. Sci. 24 (3): 371-74.
Singh, G., Gupta, S., Mishra, R. and Singh, G.P. 2005. Wedge grafting in guava - A novel vegetative propagation technique, Central Institute for Sub- tropical Horticulture, Lucknow, 12.

Singh, S., and Singh, A.K. 2006.Standardization of method and time of propagation in jamun under semi-arid environment of western India. Ind. Jour. of Agri.Sci. 76(4):242-45.

Sivudu, B.V., Reddy, M.L.N., Baburatan, P., and Dorajeerao, A.V.D. 2014. Effect of structural conditions on veneer grafting success and survival of mango grafts (Mangifera indica $c v$. Banganpalli). Plant Archives. 14(1):71-75.

Syamal, M.M., Ranjeet, K. and Mamta, J. 2012. Performance of wedge grafting in guava under different growing conditions. Ind. Jour. of Hort. 69(3): 424-27.

Taiz, L., and Zeiger, E. 2012.Text book of plant physiology. Fifth edition. Published by sinauer associate Inc publishers. Sunderland. Massachusetts. USA. 546-80.

\section{How to cite this article:}

Vanaja, L., D.V. Swami, B. Prasanna Kumar and Subbaramamma, P. 2017. Studies on the Effect of Time of Wedge Grafting and Growing Conditions on Growth and Leaf Characteristics of Guava (Psidium guajava L.) Grafts. Int.J.Curr.Microbiol.App.Sci. 6(10): 1574-1580. doi: https://doi.org/10.20546/ijcmas.2017.610.189 